\title{
ОРГАНІЗАЦІЯ ФАРМАЦЕВТИЧНОГО ТУРИЗМУ ЯК СУЧАСНОГО НАПРЯМКУ ПІДВИЩЕННЯ РІВНЯ ФІЗИЧНОЇ ТА СОЦІАЛЬНО-ЕКОНОМІЧНОЇ ДОСТУПНОСТІ ЛІКІВ В СВІТІ
}

\author{
${ }^{1}$ Канд. фарм. н, дочент Самборський О. С., ${ }^{2}$ доктор фарм. н., професор Слободянюк М. М. * \\ ${ }^{1}$ Украӥна, м. Івано-Франківськ, Івано-Франківський національний медичний університет, \\ кафедра організачї та економіки фармації та технологї \\ ${ }^{2}$ Украӥна, м. Харків, Національний фармацевтичний університет, кафедра фармацевтичного \\ менеджменту та маркетингу
}

DOI: https://doi.org/10.31435/rsglobal_ws/30092019/6711

\section{ARTICLE INFO \\ Received: 14 July 2019 \\ Accepted: 18 September 2019 \\ Published: 30 September 2019 \\ KEYWORDS \\ availability of medical care, availability of pharmaceutical care, medical tourism, pharmaceutical tourism.}

\begin{abstract}
According to the results of studies, it was found that the term «medical tourism» is used in the specialized literature to define a number of measures related to preserving life, human health, improving the appearance, etc. The term «pharmaceutical tourism» is not defined in the specialized literature. The systematization of modern experience in the functioning of medical tourism in the leading countries of the world indicates that this social phenomenon is a consequence of the implementation of various factors, including socioeconomic ones. One of the most important of these factors is the low availability of medical and pharmaceutical assistance to the population. We defined the concept of "pharmaceutical tourism", determined the forms of its implementation, objects, subjects, and also presented the main functions (medicalpharmaceutical, socio-economic, social, humanistic, market function, stimulating, foreign economic) in the healthcare system in the context of strengthening humanistic principles for the development of society.
\end{abstract}

Citation: O. Samborskyi, M. Slobodyanyuk. (2019) Organization of Pharmaceutical Tourism as a Modern Direction of Improving the Level of Physical and Socio-Economic Availability of Medicines. World Science. 9(49), Vol.2. doi: 10.31435/rsglobal_ws/30092019/6711

Copyright: (C) 2019 O. Samborskyi, M. Slobodyanyuk. This is an open-access article distributed under the terms of the Creative Commons Attribution License (CC BY). The use, distribution or reproduction in other forums is permitted, provided the original author(s) or licensor are credited and that the original publication in this journal is cited, in accordance with accepted academic practice. No use, distribution or reproduction is permitted which does not comply with these terms.

Вступ. Потреба людини у збереженні свого здоров'я на відповідному сучасним вимогам рівні $є$ однією із базових суспільних категорій, які формують основні постулати сучасного розвитку держави. За умов активного розвитку суспільства, науково-технічного прогресу та тенденцій до гуманізації суспільства потреби населення у підтримці на якісному рівні свого здоров'я зростають, об'єктивно випереджаючи матеріальні можливості суспільства та державних інституцій у всіх без виключеннях сферах діяльності суспільства. Наприкінці останнього десятиліття минулого століття виникла об'єктивна потреба окремих груп населення, які характеризувалися низьким рівням доходів, а також хворих груп у підвищенні рівня доступності надання їм медичної та фармацевтичної допомоги [1,2]. Показники доступності надання медичних та фармацевтичних послуг для пересічних громадян поступово трансформуються із категорій суто спеціальної у системі охорони здоров'я до соціально значущих у державі.

Ефективна реалізації принципів рівного доступу громадян до основних, так званих життєвонеобхідних препаратів (The Essential Drurs) в сучасних реаліях розвитку суспільства економічно розвинутих країн розглядається як важлива, але не єдина проблема. Зараз відбувається поступовий перехід моделі соціально орієнтованого доступу до необхідних для конкретної людини лікарських засобів (Л3). Персоніфікована медицина, розвиток інституту «сімейного фармацевта», 
перманентне підвищення вимог суспільства до ефективності надання медичних та фармацевтичних послуг сприяли подальшому розвитку такого феномену як «медичний й фармацевтичний туризм». Важливим фактором, який сприяє розвитку медичного та фармацевтичного туризму є наявність істотних диспропорцій у рівні надання послуг, що надаються у системі охорони здоров'я у різних країнах світу $[3,4]$. Незважаючи на значні зусилля урядів різних країн, а також міжнародних організацій, зокрема Всесвітньої організації охорони здоров'я (ВООЗ), подолати загрозливу тенденцію до розширення відриву у масштабі суспільних гарантій з надання доступних послуг у різних країнах на даний час не представляється можливим. Не є виключенням із цього переліку країн й Україна, яка лише започатковує на практиці моделі соціально орієнтовних відносин між громадянами, державою та суспільними інституціями на шляху підвищення рівня доступності надання медичних та фармацевтичних послуг. Зазначене й обумовило мету та дозволило сформулювати основні завдання досліджень.

Мета дослідження - провести аналіз розвитку світового процесу підвищення рівня фізичної та соціально-економічної доступності надання населенню фармацевтичної допомоги населенню у напрямку впровадження фармацевтичного туризму у суспільстві.

Матеріали та методи дослідження. Об'єктом досліджень стали дані спеціальної літератури, що представлені у наукометричних база 3 питань організації, проблем та перспектив розвитку як медичного, так і фармацевтичного туризму у практичній охороні здоров'я різних країн світу.

Для ефективної реалізації мети дослідження нами були сформульовані такі його завдання:

- проаналізувати дані спеціальної літератури з означеної тематики, визначити основні проблеми та перспективні напрямки розвитку такого суспільного явища, як «медичний та фармацевтичний туризм»;

- систематизувати дані з оцінки сучасного досвіду впровадження заходів з організації медичного та фармацевтичного туризму у соціально та економічно розвинутих країнах світу;

- дати визначення новому терміну, що характеризує таке суспільне явище як «фармацевтичний туризм»;

- окреслити об'єкти та суб'єкти функціонування, форми реалізації та функції фармацевтичного туризму в системі охорони здоров'я та фармацевтичного забезпечення населення.

Теоретичні дослідження проводилися з використанням цілого комплексу методів наукового пошуку та пізнання, зокрема це історичний, аналітико-порівняльний, системний, логічний, гіпотетико-дедуктивний, графічний, математико-статистичний методи наукового пошуку та пізнання.

Результати та обговорення. Як свідчать дані спеціальної літератури, найбільшого поширення факти медичного й фармацевтичного туризму набули в США, Канаді та країнах Європейського Союзу [5,6]. Так, приблизно 45,7 млн. громадян в США не мають медичних страховок унаслідок високої вартості страхових продуктів, що пропонують приватні компанії, та відсутності або обмеженого фінансового доступу до державних програм медичного страхування («Medicare», «Medicaid», «State Children's Health Insurance Program») [2,7]. Основна проблема американської та канадської системи державного медичного страхування полягає у тому, що значна кількість страхових випадків оплачується в неповному обсязі відносно вартості надання медичної та фармацевтичної допомоги. Питома вага (\%) фінансової участі громадян в оплаті таких послуг не відповідає рівню їх реальних доходів [2,8]. Так, наприклад, за програмою «Medicare» не оплачується вартість Л3, оптики та стоматологічні послуги [2]. Для вирішення цієї болючої проблеми американці та канадці змушені перетинати кордон з Мексикою задля придбання Л3, проведення планових операцій, стоматологічної допомоги, оздоровчих процедур та корекції зовнішності тощо [2,8-10]. Зазначений суспільний феномен був названий ще «транснаціональним медичним споживанням», розвиток якого, за оцінкою фахівців, дозволяс одним значно економити свої заощадження, а іншим розвивати інфраструктури медичних та аптечних закладів в країні. Цікавим $є$ той факт, що приватні страхові компанії досить активно включилися в процес організації медичного туризму на кордоні 3 Мексикою. Страховики пропонують програми медичного страхування за більш доступними цінами, що дозволяє значно підвищувати фінансові можливості громадян у сплаті вартості медичних та фармацевтичних послуг в Мексиці. В процес придбання таких страховок активно включилися i роботодавці, які сплачують частину вартості таких страховок за робітника, оминаючи високовартісні страховки, що дозволяють оплачувати відповідні послуги в США або в Канаді [11,12]. В інформаційних джерелах, іноземців, що приїздять до Мексики з метою отримання відносно дешевих та одночасно якісних медико-фармацевтичних послуг ще називають «снігові птиці» («snowbirds») 
[8]. У переважній більшості, це люди похилого віку (від 55 років та вище), що мають низькі доходи, мешкають у північних районах США або у Канаді та приїздять до Мексики на п’ять місяців та більше з метою отримання відповідних послуг в системі охорони здоров'я (проведення обстеження, виконання планових операцій, стоматологічна допомога та придбання ЛЗ).

За результатами аналізу спеціальної літератури нами встановлено, що на даний час відсутнє чітке визначення поняття «медичний туризм», а термін «фармацевтичний туризм» зовсім відсутній у науковому просторі $[2,3,8]$. Як відмічають фахівці, термін «медичний туризм» використовується для визначення цілого комплексу заходів, що пов'язані з проведенням широкого спектру медикопрофілактичних та життєвокорегуючих заходів, наприклад, від оздоровлення, косметичних процедур, пластичних операцій до складних маніпуляційних процедур та операцій у стоматології, онкології (хіміотерапія, імунотерапія раку) в т.ч. онкогематології (підбір донорів та пересадка кісткового мозку), заміни тазобедреного суглоба, репродуктивних технологій, організації надання кваліфікованої паліативної допомоги $[2,4,7,13]$. Особливе місце в цьому переліку заходів займає так званий «летальний (смертельний) туризм», метою якого є проведення євтаназії [11,14]. Як відомо, перелік країн, в яких громадяни, в т. ч. іноземці можуть добровільно покінчити з своїм життя в світі по етико-культурним, релігійним та іншим принципам вкрай обмежений. Це, насамперед, Швейцарія, Нідерланди, Бельгія, Люксембург, Канада, Колумбія, а також деякі штати США (Орегон, Вермонт й Вашингтон) [2,414].

Незважаючи на соціальну, фінансово-економічну, етно-культурну, релігійну значущість процесу підвищення рівня доступності медичних та фармацевтичних послуг за різними напрямками питання організації медичного туризму ще не набуло, на наш погляд, відповідного наукового звучання у суспільстві. Тому, важливим представляються дослідження вчених, які визначили термін «Індекс медичного туризму» (Medical Tourism Index - MTI) для окремих країн світу. За допомогою зазначеного індексу визначається організаційна, соціальноекономічна, медико-фармацевтична привабливість країни для реалізації потреби окремих громадян або групи людей у здійснені доступних та ефективних медичних й фармацевтичних послуг [14]. 3 метою визначення МТI використовуються 4 групи факторів:

- група I (оточуюче середовище та характеристика країни, наприклад, це такі фактори, як наявність стабільного обмінного курсу національної валюти відповідно до світових валют або валют тих країн, що розташовані поряд, культурна та мовна схожість, рівень злочинності в країні тощо);

- група II (наявність та рівень розвитку туристичної інфраструктури у країні);

- група III (вартісні показники, які дозволяють вимірювати рівень надання медичних й фармацевтичних послуг, оцінка можливість їх зниження);

- група IV (стан організації надання медичних та фармацевтичних послуг, наявність сертифікованих за міжнародними нормами медичних та фармацевтичних кадрів, а також рівень репутації закладів охорони здоров'я та аптек, акредитація закладів охорони здоров'я, стан матеріально-технічної бази закладів, їх оснащення тощо) [14].

За результатами проведених досліджень, які проводилися групою американських та міжнародних експертів були визначені МТI в різних країнах. Як бачимо за даними рис. 1, найвищі (від 3,0 й вище) значення зазначеного показнику були притаманні для (у порядку збільшення цифрового значення МТI) - Дубаї, Мексики, Індія, Німеччина, Таїланду, Сінгапуру та Коста-Ріка, а найнижче для - Росії $(1,98)$.

Окремого розгляду потребує питання значної різниці у вартості ЛЗ в країнах, що межують 3 одна 3 однією. Так, у табл. 1 представлені дані середньої роздрібної вартості трьох препаратів, у країнах (США, Канада, Мексика), що мають спільні кордони [8]. Як бачимо, вартість ЛЗ може різнитися у сім та більше разів. Наприклад, вартість такого препарату як Vioxx ${ }^{\circledR}, 25$ мг, що був представлений компанією «Merck» ще у 1999 році, як відносно безпечна альтернатива нестероїдним протизапальним засобам для лікування хронічного больового синдрому у ревматології, в США коштує у 7,81 рази більше, ніж у Мексиці та у 2,52 рази більше, ніж у Канаді. Зазначена проблема характерна також й для України. Так, мешканці прилеглих до Республіки Польщі областей України регулярно здійснюють туристичні тури 3 метою отримання ЛЗ за рецептами, що випасали українські лікарі [15]. 


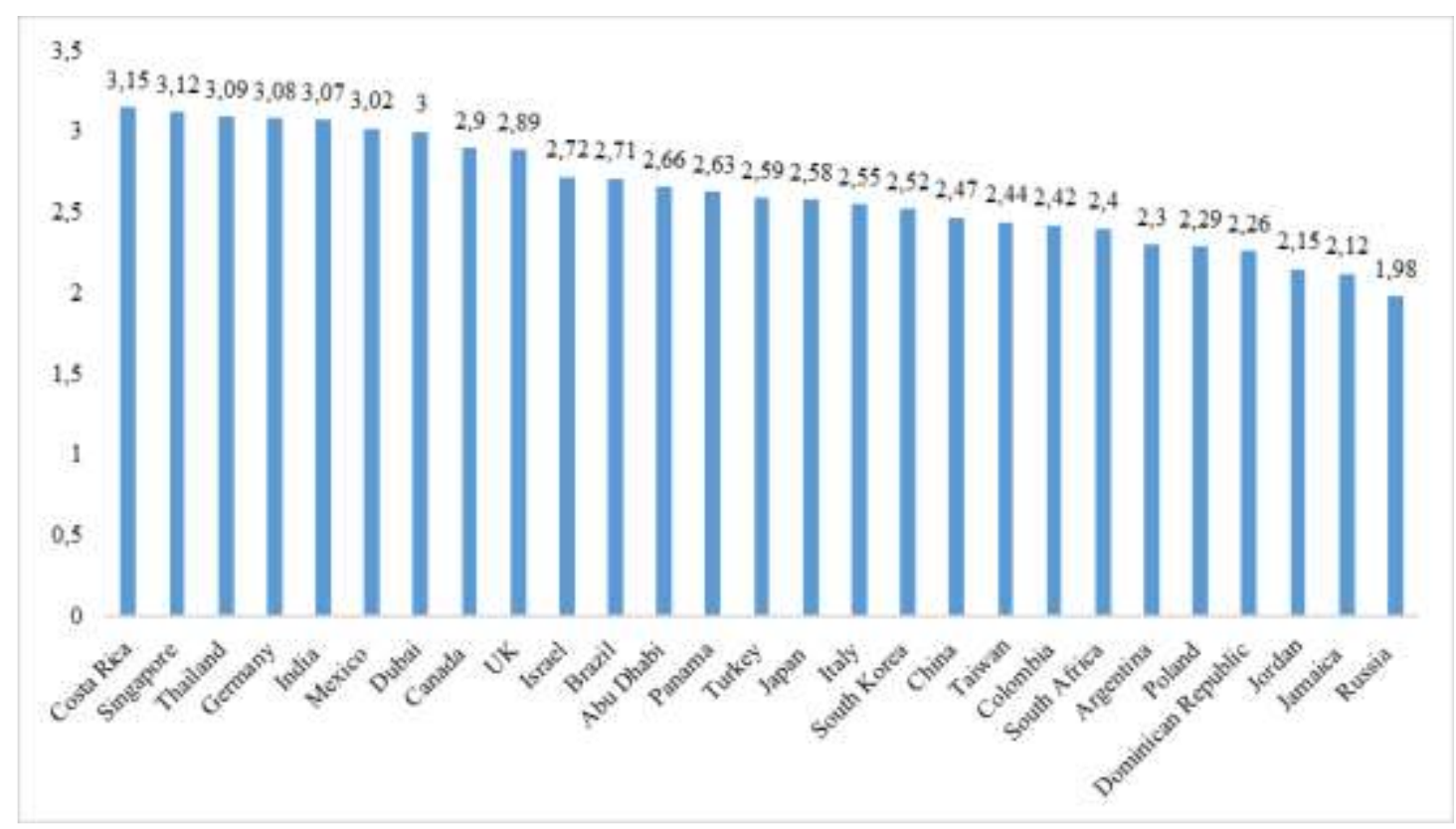

Рис.1 Аналіз індексу медичного туризму по різних краӥнах світу [14]

Таблиця 1. Порівняльна середньої роздрібної вартості ЛЗ у країнах, що мають спільні кордони [8]

\begin{tabular}{|l|c|c|c|}
\hline \multicolumn{1}{|c|}{ Торгове найменування (МНН*) Л3 } & \multicolumn{3}{|c|}{ Вартість для споживачів (дол. США) } \\
\cline { 2 - 4 } & США & Канада & Мексика \\
\hline $\begin{array}{l}\text { Vioxx } \\
\text { Suspension } 25 \mathrm{mg} \text { (Rofecoxib) Tablets and Oral }\end{array}$ & 375,00 & 149,00 & 48,00 \\
\hline $\begin{array}{l}\text { Lopressor (Metoprolol tartrate), 100 mg, injection } \\
\text { injection, solution }\end{array}$ & 17,00 & 14,00 & 8,00 \\
\hline Premarin 625 mg (Conjugated estrogens) & 32,00 & 19,00 & 8,00 \\
\hline
\end{tabular}

Примітка: - *міжнародна непатентована назва

Ще однією країною, в якій українці скуповують ліки, найчастіше використовуючи для цього туристичні поїздки, є Туреччина [16]. Враховуючи посилення тенденції до збільшення роздрібної вартості ліків, що реалізуються на внутрішньому фармацевтичному ринку в Україні, та за умов недосконалої системи реімбурсації ліків процес закупівлі ЛЗ за кордоном буде набувати все більшої популярності серед населення. Тому питання розвитку фармацевтичного туризму в Україні потребує наукового осмислення та проведення грунтовних прикладних досліджень у подальшому.

За результатами аналізу спеціальної літератури нами встановлено, що сучасні автори не відокремлюють поняття «медичний туризм» та «фармацевтичний туризм» $[3,4,17]$. Придбання ЛЗ за кордоном розглядається як важлива складова у процесі реалізації заходів з медичного туризму громадян. Зазначене явища вперше розглядалося у спеціальній літературі у контексті аналізу якості різних лікарських препаратів, що були придбані споживачами за кордоном, наприклад в Мексиці $[18,19]$. Окремі дослідження присвячені аналізу цінової привабливості тих або інших найменувань ліків та можливостей розширення доступності різних верств соціально незахищених верст населення та категорій хворих до Л3 [2,8,17]. У деяких публікаціях автори використовують поняття «фармацевтичний туризм», але не дають його визначення та розглядають як складову процесу реалізації медичного туризму $[3,10]$. Все більшої уваги приділяються розгляду питання оцінки витратної політики та досвіду у реалізації медичного туризму для управлінців охорони здоров'я [20,21]. Ми вважаємо, що фармацевтичний туризм $є$ складним та самостійним суспільним явищем, яке потребує окремого розгляду, враховуючи підвищення вимог суспільства до ефективності надання населенню фармацевтичної допомоги та особливостей державного регулювання іiі доступності на всіх етапах товаропровідної мережі в країні.

Систематизуючи результати проведених досліджень та враховуючи соціально-економічне значення розвитку фармацевтичного туризму як складного медико-фармацевтичного та 
суспільного явища нами було сформульоване його визначення. Фармацевтический туризм (pharmaceutical tourism, pharmacy tourism - анг.) - комплекс заходів, спрямованих на задоволення потреб населення у доступній фармацевтичній допомозі за межами регіону постійного проживання споживача лікарських засобів або країни в цілому. Фармацевтичний туризм, як й медичний туризм, $є$ наслідком відсутності або нерівного доступу різних верст населення з будьякого регіону постійного проживання або країни до ефективних лікарських препаратів (ЛП), фармацевтичної та медичної допомоги в цілому. Термін «фармацевтичний туризм» безпосередньо пов'язаний з поняттям фізичної та соціально-економічної доступності ЛЗ. Так, у разі відсутності необхідних препаратів на внутрішньому фармацевтичному ринку «фармацевтичний туризм» $\epsilon$ наслідком фізичної недоступності необхідних ліків, а у разі нерівного доступу окремих верст населення - $\epsilon$ наслідком соціально-економічної недоступності препаратів за умов неефективних механізмів компенсації (реімбурсації) вартості споживання ліків у країні.

Об'єктами фармацевтичного туризму є відповідні державні органі, заклади охорони здоров'я та аптеки різних форм власності та господарювання, страхові компанії, гуманітарні та суспільні організації, туристичні компанії тощо. Суб’єктами - є споживачі фармацевтичних послуг, фармацевти та провізори, представники гуманітарних та суспільних фондів або організацій, страхові агенти, надавачі туристичних послуг тощо. 3 однієї точки зору, в сучасних умовах розвитку систем охорони здоров'я фармацевтичний туризм можна розглядати як негативне соціально-економічне явище, що спостерігається у країнах 3 недосконалим механізмом державного регулювання показників доступності ЛЗ. 3 іншого, як наслідок нерівномірного розподілу ресурсів між різними верствами населення та активного процесу глобалізації, в т. ч. у охороні здоров'я та системі фармацевтичного забезпечення населення.

За формою реалізації фармацевтичний туризм може бути індивідуальним або колективним. У разі індивідуального фармацевтичного туризму фізична особа або його представник з метою придбання необхідних ЛЗ за доступною ціною або тих найменувань, що відсутні на внутрішньому фармацевтичному ринку, здійснює переїзд за межі регіону постійного проживання або країни за власні кошти. Колективний фармацевтичний туризм пов'язують 3 організацією діяльності гуманітарних, волонтерських або страхових компаній, що займаються програмами колективного (корпоративного) медичного страхування. Зазначені організації сприяють організації колективного переїзду групи фізичних осіб за межі регіону постійного проживання або країни за власні кошти або кошти суспільних й страхових фондів 3 метою придбання необхідних ЛЗ за доступною ціною або тих найменувань, що відсутні на внутрішньому фармацевтичному ринку різних країн.

У системі фармацевтичного забезпечення населення фармацевтичний туризм повинен виконувати, на нашу думку, наступні функції:

- медико-фармацевтичну (підвищення рівня ефективності надання послуг, що надаються населенню у разі втрати здоров'я або тимчасової працездатності);

- соціально-економічну (підвищення рівня фізичної та соціально-економічної доступності ЛП та фармацевтичної допомоги в цілому окремим групам населення або хворим, що у наслідок дії цілого спектру факторів не мають реальної спроможності придбати та споживати необхідні ліки);

- суспільну (сприяє розвитку ефективних зв'язків між окремими групами населення або хворими, що проживають у прикордонних областях або у сусідніх країнах в цілому);

- гуманістичну (можливість ефективної реалізації завдяки фармацевтичному туризму гуманістичного потенціалу функціонування сучасної системи фармацевтичного забезпечення у напрямку вільного вибору людиною форми та методів збереження свого здоров'я та життя за умов існуючого ресурсного забезпечення систем охорони здоров'я та власних заощаджень);

- стимулюючу (сприяє розвитку аптечної мережі країни, в яку здійснюють візити мешканці сусідньої країни за ЛЗ та наданням фармацевтичної допомоги, підвищенню рівня кваліфікації кадрів, яка повинна відповідати міжнародним нормам та вимогам. Крім цього, фармацевтичний туризм напряму дозволяє ефективно розвивати відповідної туристичну інфраструктуру у країні);

- ринкову (підвищує рівень інформатизованості споживачів про нові Л3, які поки відсутні на внутрішньому фармацевтичному ринку, розширює ринку збути ліків та опосередковано сприяє підвищенню конкуренції на внутрішньому фармацевтичному ринку);

- зовнішньо-економічну (фармацевтичний туризм сприяє розвитку процесу глобалізації національних економік та розробці більш ефективних шляхів співпраці між урядами країн, що 
межують одна з однією у напрямку впровадження більш вигідних моделей відносин між суб'єктами господарювання у системі охорони здоров’я та фармацевтичного забезпечення населення).

Безумовним $є$ той факт, що ефективна реалізації зазначених функцій неможлива без активної участі державних органів, які повинні сприяти подальшому розвитку сусідських відносин між різними країнами, а й одночасно удосконалювати форми та методи державного регулювання доступності ЛП та фармацевтичної допомоги, що надається населенню в країні.

\section{Висновки.}

1. За результатами проведених досліджень встановлено, що у спеціальній літературі термін «медичний туризм» використовується для визначення цілого спектру заходів, що пов'язані із збереження життя, здоров'я людини, корекції зовнішності тощо. Термін «фармацевтичний туризм» відсутній.

2. Систематизація сучасного досвіду проведення медичного туризму в провідних країнах світу дає змогу стверджувати, що зазначене суспільне явище є наслідком реалізації різних факторів, серед яких соціально-економічні, а саме низькій рівень доступності надання медичної та фармацевтичної допомоги займає одну із пріоритетний позицій.

3. Враховуючи сучасні тенденції до глобалізації національних економік, недосконалість механізмів державного регулювання рівня доступності надання медичної та фармацевтичної допомоги, посилення відриву між різними країнам та групами населення або хворими у ресурсному забезпеченні надання послуг у системі охорони здоров'я тенденція до розвитку медичного та фармацевтичного туризму буде й подальшому продовжуватися.

4. За результатами систематизації матеріалу нами запропоноване визначення терміну «фармацевтичний туризм», окреслені форми його реалізації, визначені об'єкти, суб'єкти та основні функції (медико-фармацевтична, соціально-економічна, суспільна, гуманістична, стимулююча, ринкова та зовнішньо-економічна) його реалізації у системі охорони здоров'я за умов посилення гуманістичних принципів розвитку громадянського суспільства.

Започатковані дослідження доцільно продовжувати у напрямку більш детального аналізу сутності та проявів фармацевтичного туризму в Україні, визначати незадоволені потреби населення у фармацевтичній допомозі та конкретних ЛЗ з метою подальшої розробки нових затребуваних у країні Л3, постановки їх на виробництво та виведення на ринок.

\section{ЛІТЕРАТУРА}

1. Devon Herrick. Shopping for Drugs: 2007. Center for Policy Analysis NCPA Policy Report №. 293 November 2006 Available from: http://www.ncpathinktank.org/pdfs/st293.pdf

2. Tanner L. Hudson. An Interdisciplinary Analysis of Medical Tourism / Tanner L. Hudson // Journal of Excellence in Integrated Writing Courses at Wright State - 2017 - №4 - P.64-74.

3. By Jeffrey Segal. Is «Pharmaceutical Tourism» Just Around the Corner? / By Jeffrey Segal // General Surgery News. -2008 - Okt. - P. 44-45.

4. Danial E. Baker Has the Time Come for «Medication Tourism»? / Danial E. Bake // Hosp Pharm. - 2014 №49(11) - P. 99-1000.

5. Medical tourism statistics and facts. Patients Beyond Borders World Edition. 2014. Available from: http://www.patientsbeyondborders.com/medical-tourism-statistics-facts.

6. Medical tourism gets and facelift and perhaps a pace-maker. Forbes, August19, 2014. Available from: http://www.forbes.com/sites/reenitadas/2014/08/19/medical-tourism-gets-a-facelift-and-perhaps-a-pacemaker/

7. The real costs of medical tourism. 2013. Available from: http://www.insurancequotes.org/health/the-realcosts-of-medical-tourism /

8. Jennifer Miller-Thayer. Health Migration: Crossing Borders for Affordable Health Care / Jennifer MillerThayer // Field Actions Science Reports The journal of field actions - 2010 - Special Issue 2. Available from: file:///C:/Users/adm/Downloads/factsreports-503.pdf

9. Casner P. R., Guerra L. G. Purchasing prescription medication in Mexico without a prescription: the experience at the border. / Casner P. R., Guerra L. G. //Western Journal of Medicine - №156(5) - P.512-516.

10. McKeithan E. K., Shepherd M. D. Pharmaceutical products declared by U.S. residents on returning to the United States from Mexico / McKeithan E. K., Shepherd M. D //Clinical Therapeutics - 1996 - №18(6) - P. 1242-1251

11. Landeck Michael, Cecilia Garza. Utilization of Physician Health Care Services in Mexico by U.S. Hispanic Border Residents / Landeck Michael, Cecilia Garza // Health Marketing Quarterly - 2002 - №20 - P. 3-16.

12. Kelly L., Karlage and Paul B. Myrdal. Mexico and the United States: A Case Study / Kelly L., Karlage and Paul B. Myrdal // Drug Development and Industrial Pharmacy - 2005 - №31 (10). -P. 993-1000. Available from: https://www.tandfonline.com/doi/abs/10.1080/03639040500306245

13. Macias E. P., Morales L. S. Crossing the Border for Health Care / Macias E. P., Morales L. S. // Journal of Health Care for the Poor and Underserved - 2001 - №12 - P. 77-87. 
14. Marc Fetscherin, Renee-Marie Stephano. The Medical Tourism Index: Scale Development and Validation. / Marc Fetscherin, Renee-Marie Stephano // Tourism Management - 2016 - № 52 - P. 539-556

15. Українці масово їдуть в Європу за ліками: навіть там дешевше. Available at: https://znaj.ua/society/206575-ukrajinci-masovo-jidut-v-yevropu-za-likami-navit-tam-deshevshe

16. В аптеку - за кордон: чому ліки в Україні коштують дорожче, ніж в Польщі. Available at: https://uk.etcetera.media/farmturi-ukrayintsiv-chomu-liki-v-polshhi-i-turechchini-v-kilka-raziv-deshevshi.html

17. Lvillo J. P., Lal L. Pilot study of a survey of U.S. residents purchasing medications in Mexico: demographics, reasons, and types of medications purchased / lvillo J. P., Lal L. // Clinical Therapeutics 2003 - №25(2) - 561-577.

18. Comparative evaluation of pharmaceutical products obtained in Mexico: augmenting existing scientific data / Kelly L. Karlage, Stephen J. Franklin, Whe Christina Mufich, Kristen J. Goetz et al. // Drug Development and Industrial Pharmacy - 2012 - №38 (7) - P. 808-814.

19. A Comparison of Pharmaceutical Product Performance of Albuterol Inhalers Available in the United States and Those Obtained in a Mexican Border Town / Meira Nocella, Emily Kilber, Brittney Witmer // Journal of Pharmacy Technology - 2015 - July 14. Available from: https://journals.sagepub.com/doi/abs/10.1177/8755122515595052

20. Karuppan Corinne Marie. Employer-Based Coverage and Medical Travel Options: Lessons for Healthcare Managers / Karuppan Corinne Marie // Journal of Healthcare Management - 2014 - №59 (3) - P. 210 -222

21. Macias E. P., Morales L. S. Crossing the Border for Health Care / Macias E. P., Morales L. S. // Journal of Health Care for the Poor and Underserved - 2001 - №12 - P. 77-87. 